УДК:023:004+378.61

Журавська Катерина Олександрівна

аспірант

Інститут інформаційних технологій і засобів навчання НАПН України, м. Київ, Україна

Katerinazh@gmail.com

\title{
АКТУАЛЬНІСТЬ СТВОРЕННЯ ЕЛЕКТРОННИХ БІБЛІОТЕК ВИЩИХ МЕДИЧНИХ НАВЧАЛЬНИХ ЗАКЛАДІВ УКРАЇНИ
}

\begin{abstract}
Анотація. Стаття присвячена аналізу наявності доступу до методичної документації вузу на сайтах вищих медичних закладів України. Проаналізовано інструменти, які забезпечують цей процес. Особливу увагу приділено використанню електронних бібліотек у медичних вузах, розглянуто проблему відкритого доступу до методичної інформації. Висвітлено перспективи використання новітніх інформаційних технологій в медичній галузі освіти. Зазначено, що використання електронних бібліотек дозволить студентам медикам краще опановувати знання та бути конкурентоспроможними спеціалістами, а навчальному закладу підвищити свій суспільний рейтинг.
\end{abstract}

Ключові слова: електронні бібліотеки; веб-сайт; медичні заклади освіти; інформаційні технології в освіті.

\section{1. ВСТУП}

Постановка проблеми На сьогодні проблема інформатизації і безпосередньо пов'язаної з нею комп'ютеризації всіх сфер людської діяльності, зокрема медицини, $\epsilon$ однією 3 глобальних проблем сучасного світу. Причиною $\epsilon$ стрімкий розвиток медицини за рахунок сучасних досягнень генетики, молекулярної біології, фармакології, комп'ютерних технологій. Ці досягнення призводять до появи нових діагностичних i лікувальних підходів, застосування яких вимагає підготовки висококваліфікованих фахівців. Тому, впровадження інформаційних технологій у навчальний процес вищих медичних закладів освіти є логічним і необхідним кроком для розвитку сучасного інформаційного світу і $є$ важливим компонентом підготовки студентів-медиків до професійної діяльності.

Якість освіти в сучасному інформаційному середовищі напряму залежить від форм подання навчальних матеріалів. Загальновідомим $є$ факт, про те, що протягом багатьох років важливим засобом забезпечення навчальної i наукової діяльності студентів була і залишається бібліотека. Проте зі стрімким збільшенням кількості наукових і навчальних матеріалів, особливо електронних, саме електронні бібліотеки створюють умови для ефективного забезпечення науковців своєчасними, достовірними та повними відомостями. Електронні бібліотеки значно еволюціонували за останні кілька років. Це вже не лише перелік назв повнотекстових документів на сайті, а складні мережні системи, які мають технології обміну даними між різними бібліотеками в усьому світі [16, с. 101].

Електронна бібліотека має цілу низку переваг в плані ефективного забезпечення інформаційного освітнього простору. Бібліотека спільно з іншими підрозділами вузу здатна стати організаційною структурою, що забезпечує формування, організацію i надання доступу до колекції електронних ресурсів. Удосконалення правового, кадрового та фінансового забезпечення інформатизації бібліотечної сфери дозволить створити ефективну інформаційну складову освітнього простору. Формування єдиного інформаційного простору вузу 3 використанням інформаційно-комунікаційних технологій (IКТ) може бути передумовою інтеграції в єдине інформаційно-освітнє 
середовище 3 метою оптимізації розподіленого доступу до інформаційних ресурсів, прискорення обміну освітньою та науковою інформацією.

Аналіз останніх досліджень i публікацій. Сучасними тенденціями та перспективами розвитку електронних бібліотек займаються вчені, зокрема: Спірін О. М.[16-17], Новицький О. В.[17], Олексюк О. Р. [13; 16], Іванова С. М. [12], Яцишин А. В. [19] та ін. У їхніх працях розглядаються теоретичні та практичні питання створення i функціонування електронних бібліотек. Окремі питання використання інформаційних технологій у медичній освіті висвітлені у роботах: Амбрушкевича Ю. Г. [1], Божка Г. Г. [14], Гарелик П. В. [11], Гущиної Л. М. [7], Дубровщика О. І. [11], Каравай А. В. [14], Мармиша Г. Г. [11], Могилевец Э. В. [11], Угляница К. Н. [14] та інших. У попередній публікації автора [9] частково розглянуто питання актуальності створення електронних бібліотек у вищих медичних навчальних закладах. Проте комплексного дослідження щодо створення електронних бібліотек у вищих медичних навчальних закладах проведено не було і тому ця проблема $\epsilon$ актуальною і своєчасною.

Мета статті - проаналізувати веб-сайти вищих медичних навчальних закладів на наявність відкритого доступу до навчальної та медичної літератури і документації, розглянути доступність, зручність та наповненість головного веб ресурсу Вузу.

\section{2. РЕЗУЛЬТАТИ ДОСЛІДЖЕННЯ}

У публікації [11, с. 31-32] зазначено, що навчання студентів у вищому медичному навчальному закладі відрізняється певною специфікою в порівнянні 3 отриманням вищої освіти в інших навчальних закладах. Насамперед це стосується розвитку у майбутнього медичного працівника клінічного лікарського мислення, вміння застосувати свої знання в екстрених ситуаціях, навичок спілкування з пацієнтами. Для досягнення цієї мети використовуються різні форми навчання, психологічні та педагогічні прийоми. У тому числі важливу роль відіграють ІКТ та електронні засоби навчання.

Оскільки Україна активно інтегрується у світове суспільство, випускникам вищих медичних навчальних закладів потрібно постійно розширювати і вдосконалювати свої знання. Необхідно використовувати IКТ для вдосконалення навичок та вмінь у медичній практиці. В медичних вузах активно впроваджується кредитно модульна система навчання, яка вимагає від студента більше уваги приділяти самостійній роботі. Але студенти не завжди можуть вільно орієнтуватися в інформаційному середовищі та працювати самостійно. Для порівняння у Великій Британії реформа медичної освіти пройшла ще в 90 роках минулого сторіччя [8]. Це суттєво вплинуло на рівень професійної підготовки та якість медичних послуг. В країнах Західної Європи медична сестра виконує не тільки призначення лікаря, а й може вплинути на лікувальний процес. Це поняття називають «медсестринський діагноз». Така організація лікувального процесу ефективна ще й тому, що допомагає розвантажити лікаря, дозволяє йому зосередитися на більш складних проблемах.

В сучасних умовах розвитку суспільства прогрес медицини пов'язаний із застосуванням цілого ряду нових методів діагностики та комп'ютерних технологій. I тому важливою формою вдосконалення системи навчання студентів-медиків $\epsilon$ впровадження в навчальний процес нових методик навчання та інформаційнокомунікаційних технологій.

У публікації [1, с. 8] наголошується на тому, що для підвищення якості навчання використовуються інформаційні ресурси глобальної мережі. Перевагою використання комп'ютерних технологій $є$ те, що методичні матеріали, що надаються через мережу 
Інтернет, мають можливість регулярного оновлення і доповнення. Крім того, для подання навчального матеріалу можуть бути використані сучасні технології візуального представлення. А доповнення традиційних методів викладання Інтернеттехнологіями посилює мотивацію студентів до вивчення предметів. Також, ІКТ є важливим засобом на шляху до підготовки висококваліфікованих кадрів у сфері медицини, готових постійно підвищувати свою кваліфікацію.

Подібний висновок до попереднього зроблено у роботі Гущиної Л.М. [7, с. 40], де зазначено, що для успішної особистісної та професійної реалізації в сучасному суспільстві викладачеві і студенту необхідно навчитися швидко орієнтуватися в потоках різноманітної інформації, гнучко реагувати на істотні зміни, систематично підвищувати свою кваліфікацію. Авторка описує свій досвід роботи у вищому медичному навчальному закладі: «В університеті для супроводу всіх лекцій застосовуються мультимедійні презентації. Вони також широко застосовуються і на практичних заняттях, особливо на клінічних заняттях $з$ використанням спеціальних програм або створених відеофільмів. Це прискорює процес придбання знань і навичок за рахунок збільшення ефективності практичних i лабораторних занять завдяки економії навчального часу. Спрощується підготовка, добірка і модифікація навчальних матеріалів» [7, с. 42].

Погоджуємося 3 думкою, висловленою у роботі [11, с. 68], про те, що реформування системи освіти вимагає модернізації навчального процесу, пошуку ефективних форм і методів роботи зі студентами. Нові державні освітні стандарти орієнтують на якісні параметри організації навчального процесу. Це вимагає вирішення двох взаємопов'язаних завдань: підвищення ефективності аудиторних занять i самостійної роботи студентів.

Заняття із застосуванням сучасних IКТ - це якісно нова форма навчання, на яку викладач погоджує методику вивчення нового матеріалу з методикою застосування комп'ютерних технологій, дотримуючись спадкоємності по відношенню до традиційних педагогічних технологій.

Групою авторів у роботі [11, с. 68-69] зазначено, що розвиток науково-технічного прогресу, вдосконалення педагогічної науки взагалі і вищої школи диктують необхідність використання їх досягнень, у тому числі і в процесі викладання на клінічних кафедрах медичних вузів. 3 досвіду, оптимальних результатів навчання вдається досягти при дотриманні в навчальній роботі певного алгоритму. Необхідною умовою $\epsilon$ самостійна позааудиторна підготовка 3 використанням спеціальної навчальної, наукової та дидактичної літератури. Важливу роль у засвоєнні матеріалу відіграє контроль самопідготовки, в ході якого викладач звертає увагу на можливі упущення, основні, найбільш значущі і найбільш складні питання досліджуваної теми.

Зауважимо, що сучасна молодь надає перевагу інформаційним ресурсам в електронному вигляді, нехтуючи друкованими виданнями. Електронна форма подання навчальної інформації є зручною альтернативою традиційним паперовим навчальним матеріалам: підручникам, посібникам, журналам тощо [11, с. 68-69]. «Немає жодного студента, який би хоча б раз у житті не використовував електронні ресурси у своїй пізнавальній діяльності та науковій роботі. Переважна більшість молоді використовує їх щоденно, переглядаючи значну кількість веб-сторінок», наголошено у статті [13]. Тому, перед студентами ставиться завдання з пошуку медичної інформації в Інтернеті і подальшої роботи з нею, рекомендуються для самостійного вивчення окремі електронні матеріали, записи томографії з різними видами патології, навчальні фільми, медичні сайти тощо.

Водночас, величезні потоки цифрових матеріалів ставлять студента перед необхідністю аналізувати значну кількість публікацій. Друга проблема, що виникає у 
процесі роботи з такими відомостями - достовірність мережних ресурсів. Для значної частини інформаційних ресурсів мережі Інтернет характерні хаотичні і нерівнозначні за науковою цінністю матеріали [13].

На сьогодні у вищих медичних навчальних закладах закумульовано значну кількість навчального матеріалу в електронному виді (відеозаписи, аудіозаписи, презентації, посібники, підручники, дисертації, навчальні програми, методичні рекомендації тощо). Важливим $є$ збереження цих матеріалів і надання вільного доступу до них для студентів і викладачів. Ефективним вирішенням окресленої проблеми $\epsilon$ створення електронних бібліотек вищих медичних навчальних закладів України. Адже інформаційні матеріали представлені в електронній бібліотеці закладу $\epsilon$ структурованими з можливістю швидкого пошуку: за ключовими словами, за автором, за роком видання, за кафедрою, з доступом у будь-який час.

Опишемо основні переваги використання електронних бібліотек у навчальновиховному процесі ВНЗ:

1) зменшення вартості публікації i поширення наукових, навчальних, нормативних матеріалів через використання IКТ і мережі Інтернет;

2) скорочення часу опублікування результатів дослідження. Змінюється традиційна схема поширення наукового матеріалу, який замість послідовності автор видавець - журнал - бібліотека - читач, дістається читача лише засобами інституційного репозитарію (автор - електронна бібліотека - читач);

3) збільшення обсягу фондів бібліотеки, оскільки кількість збережених у них матеріалів практично не обмежується фізичними параметрами сховища;

4) забезпечення доступу до рідкісних документів;

5) збереження й поширення наукових і навчальних матеріалів у різних форматах (малюнки, бази даних, діаграми, аудіо і відео файли тощо);

6) архівування раніше не збережених даних (лабораторних журналів, фотографій, рисунків, звуків та відеоінформації);

7) забезпечення ефективного пошуку матеріалів, зокрема повнотекстового. Підвищення активності науково-дослідницької діяльності, оскільки пошук інформації $є$ початковим етапом кожного наукового дослідження;

8) надання доступу до публікацій у будь-який час і 3 будь-якого пристрою (комп’ютер, нетбук, планшет, мобільний телефон, смартфон тощо), який підключений до мережі Інтернет [16, с. 102].

Погоджуємось із твердженням у публікації [16, с. 112], про те, що можливість збереження в інституційному репозитарії/електронній бібліотеці інтелектуального продукту, створеного у вищому навчальному закладі, на основі самостійного внесення авторами власних публікацій змінила аспекти формування фондів університетських бібліотек. Такий репозитарій значно спрощує публікування результатів досліджень у різних форматах (тексти, малюнки, бази даних, діаграми, аудіо та відео файли тощо) i сприяє відкритому доступу до них; забезпечує ефективний пошук електронних ресурсів; дозволяє презентувати і популяризувати результати наукових досліджень і навчальні курси ВНЗ, сприяє створенню електронного наукового середовища навчального закладу, інтегрованого в європейський і міжнародний науково-освітній простір.

Тому нами було проведено дослідження веб-сайтів декількох вищих медичних навчальних закладів України, у ході якого з'ясовано, що не всі заклади мають інституційні репозитарії/електронні бібліотеки. Аналіз цих сайтів представлено у таблиці 1. Розділи таблиці були складені з позиції подання методичної документації для студентів. 
Аналіз головних сайтів вищих медичних закладів освіти

\begin{tabular}{|c|c|c|c|c|}
\hline навчального & $\begin{array}{l}\text { Наявність електронної } \\
\text { бібліотеки } \quad \text { (назва } \\
\text { бібліотеки) на сайті }\end{array}$ & $\begin{array}{l}\text { Характеристика } \\
\text { ресурсу }\end{array}$ & $\begin{array}{l}\text { Наявність ресурсів для } \\
\text { вільного користування }\end{array}$ & Особливості сайту \\
\hline $\begin{array}{l}\text { Вінницький } \quad \text { медичний } \\
\text { університет ім.M.І.Пірогова }\end{array}$ & Бібліотека & $\begin{array}{ll}\text { Електронний } & \text { каталог, } \\
\text { інформація про періодику } \\
\text { та посилання } & \text { на сайти } \\
\text { основних } & \text { медичних } \\
\text { журналів. } & \end{array}$ & $\begin{array}{l}\text { Вільного доступу до } \\
\text { ресурсів бібліотеки не має, } \\
\text { інформація надається тільки } \\
\text { у вигляді анотації. }\end{array}$ & $\begin{array}{l}\text { Навчально-методичну } \\
\text { документацію для студентів } \\
\text { можна завантажити } \\
\text { зайшовши на кафедру, } \\
\text { вкладка студента. }\end{array}$ \\
\hline $\begin{array}{l}\text { Тернопільський } \\
\text { університет }\end{array}$ & Інтранет & $\begin{array}{l}\text { Інформація } \\
\text { структурована } \\
\text { розділами, організовано } \\
\text { пошук, вибір мови } \\
\text { перегляду. }\end{array}$ & $\begin{array}{lcc}\text { Інформацію } & \text { можна } \\
\text { переглянути } & \text { тільки } & \text { маючи } \\
\text { пароль. } & & \end{array}$ & $\begin{array}{l}\text { На сайті є окремий розділ } \\
\text { (репозитарій) } \\
\text { навчальних програм. }\end{array}$ \\
\hline $\begin{array}{l}\text { Буковинський } \quad \text { державний } \\
\text { медичний університет }\end{array}$ & $\begin{array}{l}\text { Цифровий репозитарій } \\
\text { розроблений на } \\
\text { платформі DSpase }\end{array}$ & 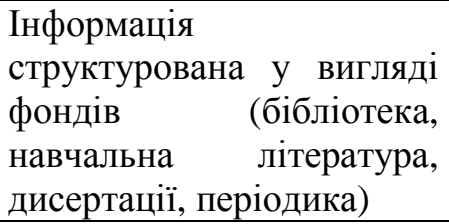 & $\begin{array}{lr}\text { Для повного } & \text { доступу до } \\
\text { документації } & \text { необхідно } \\
\text { авторизуватися. } & \end{array}$ & \\
\hline $\begin{array}{l}\text { Запорізький державний } \\
\text { медичний університет }\end{array}$ & Бібліотека & $\begin{array}{lr}\text { Електронні } & \text { ресурси } \\
\text { кафедр, } & \text { електронні } \\
\text { документи. } & \end{array}$ & $\begin{array}{lrr}\text { Доступ до } & \text { інформації } \\
\text { надається } & \text { тільки } \\
\begin{array}{l}\text { працівникам } \\
\text { вузу. }\end{array} & \text { та } & \text { студентам } \\
\end{array}$ & \\
\hline $\begin{array}{l}\text { Одеський } \quad \text { національний } \\
\text { медичний університет }\end{array}$ & Електронна бібліотека & $\begin{array}{ll}\text { Перелік } & \text { електронних } \\
\text { підручників } & \end{array}$ & $\begin{array}{l}\text { Доступ здійснюється через } \\
\text { локальну } \\
\text { університету. } \\
\end{array}$ & \\
\hline $\begin{array}{l}\text { Дніпропетровська медична } \\
\text { академія } \quad \text { Міністерства } \\
\text { охорони здоров'я України } \\
\end{array}$ & & & & $\begin{array}{l}\text { Матеріали розміщені на } \\
\text { сайтах кафедр. }\end{array}$ \\
\hline $\begin{array}{l}\text { Луганський державний } \\
\text { медичний університет }\end{array}$ & Електронні ресурси & $\begin{array}{l}\text { Періодичні видання та } \\
\text { видання на CD та DVD } \\
\text { дисках. }\end{array}$ & $\begin{array}{l}\text { Тільки ознайомлення } \\
\text { назвами документів }\end{array}$ & $\begin{array}{l}\text { Користувачам запропоновані } \\
\text { електронні посилання на } \\
\text { репозитарії інших медичних } \\
\text { вузів }\end{array}$ \\
\hline
\end{tabular}


ISSN Online: 2076-8184. Інформаційні технології і засоби навчання, 2015, Том 47, №3.

\begin{tabular}{|c|c|c|c|c|}
\hline $\begin{array}{ll}\text { Назва } & \text { навчального } \\
\text { закладу } & \end{array}$ & $\begin{array}{l}\text { Наявність електронної } \\
\text { бібліотеки } \\
\text { бібліотеки) на сайті } \\
\end{array}$ & $\begin{array}{l}\text { Характеристика } \\
\text { ресурсу }\end{array}$ & $\begin{array}{l}\text { Наявність ресурсів для } \\
\text { вільного користування }\end{array}$ & Особливості сайту \\
\hline $\begin{array}{l}\text { Харківський } \quad \text { національний } \\
\text { медичний університет }\end{array}$ & $\begin{array}{l}\text { Репозитарій } \\
\text { розроблений на } \\
\text { платформі Dspase }\end{array}$ & $\begin{array}{l}\text { Інформація } \\
\text { структурована у вигляді } \\
\text { фондів(бібліотека, } \\
\text { навчальна література, } \\
\text { дисертації, періодика) }\end{array}$ & $\begin{array}{lr}\text { Для повного } & \text { доступу до } \\
\text { документації } & \text { необхідно } \\
\text { авторизуватися. } & \end{array}$ & \\
\hline $\begin{array}{l}\text { Донецький } \quad \text { національний } \\
\text { медичний університету імені } \\
\text { М. Горького } \\
\end{array}$ & $\begin{array}{lr}\text { Інформація } & \text { про } \\
\text { електронну } & \text { бібліотеку } \\
\text { відсутня } & \\
\end{array}$ & & & \\
\hline $\begin{array}{l}\text { Національний } \\
\text { фармацевтичний університет }\end{array}$ & $\begin{array}{l}\text { Репозитарій } \\
\text { розроблений на } \\
\text { платформі Dspase }\end{array}$ & $\begin{array}{l}\text { Інформація } \\
\text { структурована у вигляді } \\
\text { фондів(бібліотека, } \\
\text { навчальна література, } \\
\text { дисертаціі, періодика) }\end{array}$ & $\begin{array}{lr}\text { Для повного } & \text { доступу до } \\
\text { документації } & \text { необхідно } \\
\text { авторизуватися. } & \end{array}$ & \\
\hline $\begin{array}{l}\text { Кримський державний } \\
\text { медичний університет імені } \\
\text { C.I. Георгієвського }\end{array}$ & $\begin{array}{lr}\text { Інформація } & \text { про } \\
\text { електронну } & \text { бібліотеку } \\
\text { відсутня } & \\
\end{array}$ & & & \\
\hline $\begin{array}{l}\text { Житомирський } \\
\text { медсестринства }\end{array}$ & Інтранет & $\begin{array}{l}\text { Документація } \\
\text { структурована за назвою } \\
\text { відділення. }\end{array}$ & $\begin{array}{l}\text { Інформація доступна тільки } \\
\text { за наявністю } \\
\text { доступу. }\end{array}$ & \\
\hline $\begin{array}{l}\text { Івано-Франківський } \\
\text { національний } \\
\text { університет }\end{array}$ & $\begin{array}{lr}\text { Інформація } & \text { про } \\
\text { електронну } & \text { бібліотеку } \\
\text { відсутня } & \\
\end{array}$ & & & \\
\hline $\begin{array}{l}\text { Львівський національний } \\
\text { медичний університет імені } \\
\text { Данила Галицького }\end{array}$ & & & & $\begin{array}{lr}\text { Методична } & \text { інформація } \\
\text { знаходиться } & \text { на } \begin{array}{c}\text { сайтах } \\
\text { кафедр }\end{array} \\
\end{array}$ \\
\hline $\begin{array}{l}\text { Національний } \\
\text { університет ім. Богомольця }\end{array}$ & & & & $\begin{array}{l}\text { Користувачам } \\
\text { пропонуються посилання на } \\
\text { сайти відкритих медичних } \\
\text { бібліотек. } \\
\end{array}$ \\
\hline $\begin{array}{l}\text { Українська } \\
\text { стоматологічна академія }\end{array}$ & Електронна бібліотека & $\begin{array}{l}\text { Організований пошук в } \\
\text { електронному каталозі }\end{array}$ & $\begin{array}{l}\text { Доступ здійснюється через } \\
\text { локальну } \\
\text { університету. }\end{array}$ & \\
\hline
\end{tabular}


Всього було проаналізовано шістнадцять офіційних веб-сайтів вищих медичних навчальних закладів. На рис. 1 показано наповненість сайтів інформацією про електронні засоби збереження навчальної літератури, статей тощо. Більшість закладів мають електронні бібліотеки, або репозитарії, деякі навчальні заклади розміщують навчальну документацію на окремих сайтах кафедр, про що інформують користувачів головного сайту. Частина вузів надають тільки заголовки документів, для того щоб ознайомитися зі змістом необхідно звернутися до звичайної бібліотеки цих закладів або локальної мережі. I тільки кілька університетів надають повний відкритий доступ до матеріалів бібліотек, як правило це зміст статей та монографій. Деякі навчальні заклади встановлюють пароль на захист навчально-методичної документації і для того щоб скористатися, потрібно бути викладачем або студентом даного навчального закладу. На рис. 2 зображено у процентному співвідношенні відкритий доступ до навчальних та методичних матеріалів представлених на веб-сайтах вищих медичних навчальних закладів України.

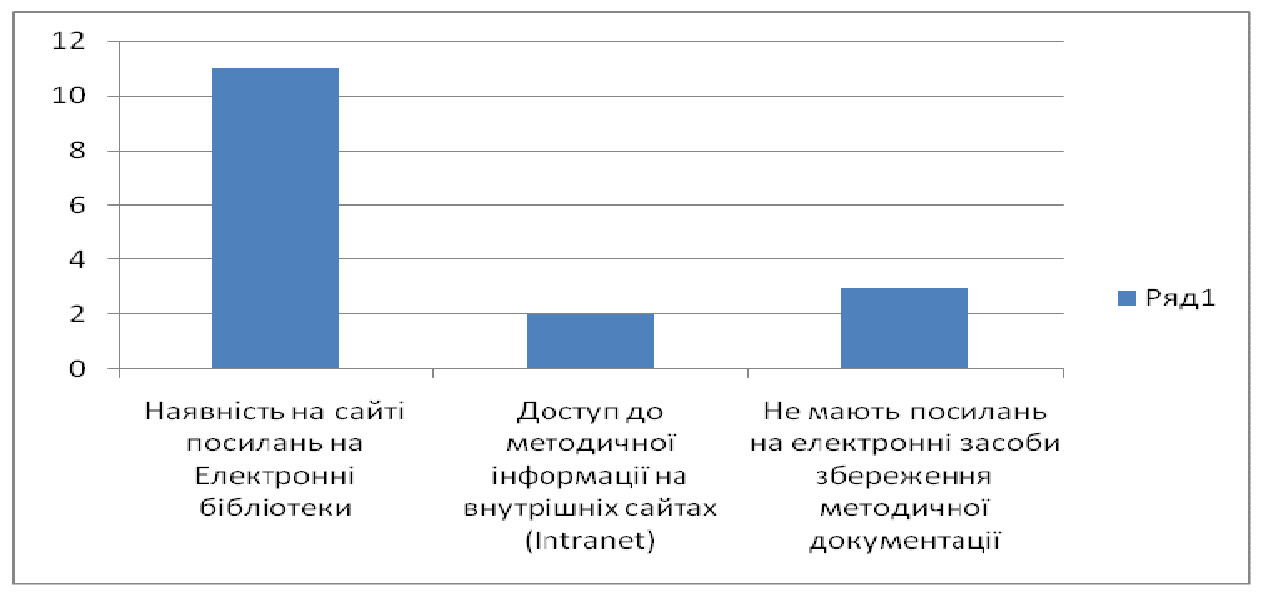

Рис. 1. Наповненість головних сайтів медичних закладів освіти.

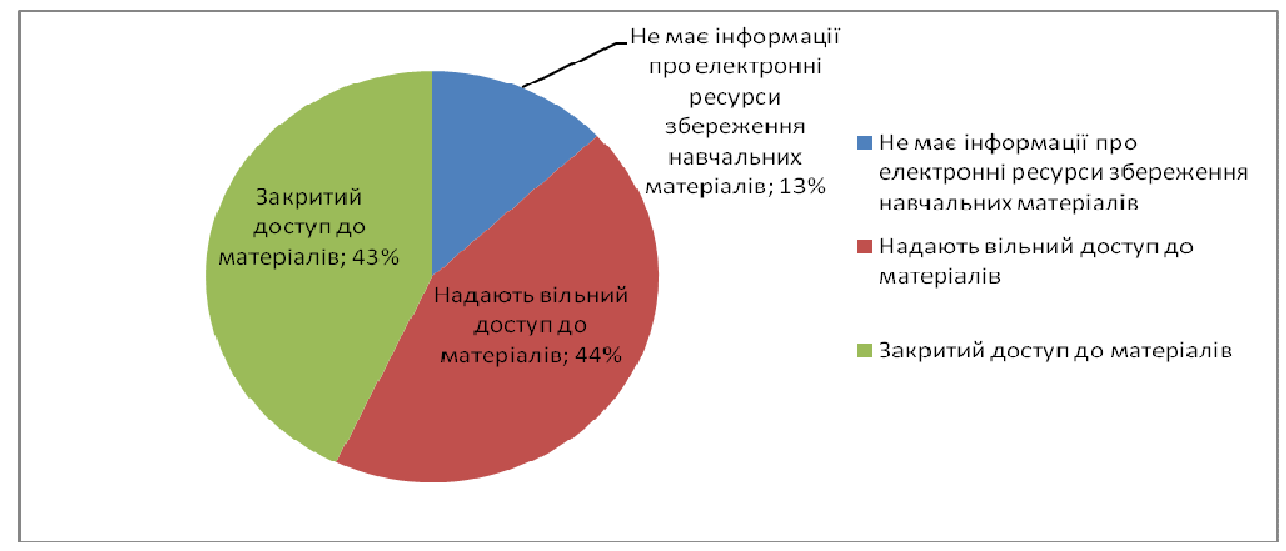

Рис. 2. Доступ до інформації на сайтах медичних закладів освіти

На рис. 1, зображено, що половина вищих медичних навчальних закладів, із досліджених, мають посилання на електронні бібліотеки, які можуть забезпечити студентів необхідною методичною та медичною літературою. Данні у відсотковому вигляді мають такий розподіл: 87\% навчальних медичних закладів мають на головних веб-сайтах інформацію про електронні бібліотеки/репозитарії. Проте, вільний доступ до цих матеріалів надають лише 44\% вузів, а у решти $43 \%$ - 3 матеріалами можна ознайомитися тільки тоді, коли маєш безпосереднє відношення до закладу. Як правило, 
це зумовлено захистом авторського права. В багатьох зарубіжних країнах цю проблему вирішують шляхом ліцензування.

Електронні бібліотеки України функціонують згідно статті 34 Конституції України («вільно збирати, зберігати, використовувати та поширювати інформацію усно, письмово або в інший спосіб - на свій вибір»). На законодавчому рівні поняття «електронна бібліотека» досі не має, їі функціонування цілком підпадає під дію Закону України «Про бібліотеки та бібліотечну справу». Але колекції документів в електронній формі сьогодні створюються різними організаціями, навчальними та науковими закладами з метою забезпечення своєї власної роботи [10].

Нині багато науковців розглядають проблему відкритого доступу до навчальних та наукових матеріалів, зокрема у статті Яцишин А.В. [19, с. 3-4] проналізовано поняття «відкритий доступ» і зроблено висновок, «що це необмежений доступ до освітніх і наукових матеріалів за допомогою комп'ютерних технологій (мережі Інтернет). Також, існує міжнародний рух, що має на меті забезпечення відкритого доступу для всіх членів суспільства до освітніх ресурсів, культурного надбання, результатів наукових досліджень. Рух відкритого доступу у науковій і освітній спільноті набуває широких масштабів $з$ початку 1990-х років із поширенням комп'ютерів й Інтернету, що забезпечило технічні можливості для реалізації принципу відкритого доступу на якісно новому рівні».

Одне 3 основних завдань підготовки майбутніх фахівців полягає у формуванні вміння знаходити та використовувати якісні електронні освітні ресурси науковоосвітнього інформаційного простору. Одним із засобів швидкого доступу до якісних електронних освітніх ресурсів $\epsilon$ інституційні репозитарії навчальних закладів, в яких навчальні та методичні матеріали знаходяться у відкритому доступі. Саме електронні бібліотеки значно підвищують рівень надання бібліотечних послуг та сприяють ефективному доступу до наявних електронних інформаційних ресурсів у мережі Інтернет, насамперед до бібліотек та періодичних видань, а також до зарубіжних електронних ресурсів; забезпечують якісно новий рівень задоволення інформаційних потреб завдяки використанню новітніх бібліотечно-інформаційних технологій (кількість доступних інформаційних джерел, ступінь їх релевантності, актуальність, повнота й оперативність отримання інформації) [13].

Отже, підручники, посібники, статті, у сучасних умовах, простіше і швидше знайти в мережі Інтернет за допомогою будь-якого мобільного пристрою чи комп'ютера. Тому студенти і віддають перевагу електронним версіям навчальних та довідкових матеріалів, оскільки вони не обмежені режимом роботи бібліотеки чи кількістю одного примірника підручника.

\section{3. ВИСНОВКИ ТА ПЕРСПЕКТИВИ ПОДАЛЬШИХ ДОСЛІДЖЕНЬ}

В сучасних умовах із застосуванням цілого ряду нових методів діагностики та комп'ютерних технологій став помітним прогрес медицини. Завдяки впровадженню у навчальний процес нових методик навчання та ІКТ вдосконалюються системи навчання студентів, зокрема - майбутніх медиків. Оскільки у вищих медичних навчальних закладах впроваджена кредитно модульна система навчання, збільшилась кількість годин для заняття самостійною роботою. Нажаль, більшість студентів не в змозі самі вільно орієнтуватися в інформаційному середовищі, відшукувати достовірний матеріал та літературу для підготовки до навчальних занять, адже мережа Інтернет переповнена різнорідними відомостями, що часто не є достовірними. Це впливає на рівень професійної підготовки та подальшу якість медичних послуг.

Вважаємо, що відкритий доступ до електронних бібліотек/інституційних репозитаріїв ВНЗ надасть великі можливості для обміну інформацією та забезпечить 
студентів навчальними та довідковими матеріалами. Відзначимо, що завдяки електронним бібліотекам/ інституційним репозитаріям медичні навчальні заклади сформують гідний інформаційний імідж, оскільки матеріали, що в них зберігаються та є у відкритому доступі - ретельно підібрані, упорядковані, і містять об'єктивні результати досліджень.

У дослідженні було проаналізовано шістнадцять офіційних веб-сайтів вищих медичних навчальних закладів та зроблено висновок про те, що створення електронних бібліотек вищих медичних навчальних закладів України $є$ актуальним і затребуваним, оскільки студенти-медики будуть мати доступ до необхідних навчальних та довідкових матеріалів у будь-який час, зможуть розвивати свою інформаційно-комунікаційну компетентність, а навчальний заклад підвищить свій суспільний рейтинг, та зможе представити напрацювання науково-педагогічного колективу у світовому освітньому просторі. В умовах конкуренції гідний рівень освіти надають ті навчальні заклади, які активно впроваджують IКТ у навчально-виховний процес. Також, використання електронних ресурсів зростатиме тоді, коли зростатиме кількість електронних бібліотек і здійснюється постійне наповнення їх якісними інформаційними ресурсами.

Крім того, важливим є подальше дослідження щодо підвищення IKTкомпетентності як майбутніх медичних працівників, так і практикуючих медиків.

\section{СПИСОК ВИКОРИСТАНИХ ДЖЕРЕЛ:}

1. Амбрушкевич Ю. Г. Современные информационные технологии в образовательном пространстве медицинского вуза: проблемы и перспективы / Ю. Г. Амбрушкевич // Использование информационных образовательных технологий и электронных средств обучения в вузе: материалы научно-методической конференции / ответственный ред. В.А. Снежицкий. - Гродно: ГрГМУ, 2011. - С. 6-8.

2. Веб-сайт Буковинського медичного університету [Електронний ресурс] - Режим доступу: http:// http://www.bsmu.edu.ua. - дата доступу 12.04.2014.

3. Веб-сайт Вінницького медичного університету ім. М.І.Пирогова [Електронний ресурс] - Режим доступу: http://www.vnmu.edu.ua. - дата доступу 27.02.2014.

4. Веб-сайт Одеського медичного університету [Електронний ресурс]. - Режим доступу: http://www. odmu.edu.ua. - дата доступу 13.03.2014.

5. Веб-сайт Тернопільського державного медичного університету ім. І.Я. Горбачевського [Електронний ресурс]. - Режим доступу: http://www.tdmu.edu.te.ua/ - дата доступу 13.03.2014.

6. Гребеник Ю. С. Аналіз сучасного стану медичної освіти у коледжах Великої Британії / Ю. С. Гребенюк // Международное сотрудничество в образовании в условиях глобализации: материалы II международной конференции. - Симферополь: ДИАЙП, 2013. - С.114-116

7. Гущина Л. Н. Инновационные образовательные технологии в высшей школе / Гущина Л. Н. // Использование информационных образовательных технологий и электронных средств обучения в вузе: материалы научно-методической конференции / ответственный редактор В.А. Снежицкий. Гродно: ГрГМУ, 2011. - С. 40-43.

8. Електронні бібліотечні інформаційні системи наукових і навчальних закладів: монографія / [Спірін О. М., Іванова С. М., Новицький О. В. та ін.]; за наук. ред. проф. В. Ю. Бикова, О. М. Спіріна. - К.: Педагогічна думка, 2012. - 176 с.

9. Журавська К. О. Актуальність створення електронних бібліотек вищих медичних навчальних закладів України / К. О. Журавська // Звітна наукова конференція Інституту інформаційних технологій і засобів навчання НАПН України: Матеріали наукової конференції ІІТЗН НАПН України. - К: ІІТЗН НАПН України, 2014. - С. 172-174.

10.Закон України про бібліотеки і бібліотечну справу [Електронний ресурс] - Режим доступу: http://library.kr.ua/zakbibsprv.html. - дата доступу 26.04.2014.

11.Использование современных интернет-технологий в учебно-образовательном процессе на кафедре общей хирургии / [Гарелик П. В., Мармыш Г. Г., Дубровщик О. И., Могилевец Э. В.] // Использование информационных образовательных технологий и электронных средств обучения в вузе: материалы научно-методической конференции / ответственный ред. В.А. Снежицкий. Гродно: ГрГМУ, 2011. - С. 31-33.

12. Іванова С. М. Тенденції використання електронних бібліотек в наукових і навчальних закладах (зарубіжний і вітчизняний досвід) [Електронний ресурс] / С. М. Іванова // Інформаційні технології 
i засоби навчання. - $2011 \quad$ - № 3 (23). http://journal.iitta.gov.ua/index.php/itlt/article/view/500.

13. Олексюк О. Аналіз використання електронних ресурсів у науково-дослідній роботі майбутніх вчителів інформатики / О. Р. Олексюк // Наукові записки. Серія: проблеми методики фізикоматематичної і технологічної освіти. - №5. - 2014. - С. 43-48.

14. Особенности преподавания онкологии с использованием систем телекоммуникаций / Каравай А. В., Угляница К. Н., Божко Г. Г. и др. // Использование информационных образовательных технологий и электронных средств обучения в вузе: материалы научнометодической конференции / ответственный ред. В. А. Снежицкий. - Гродно: ГрГМУ, 2011. С. 68-69.

15. Перетворення навчання в знання, методи навчання [Електронний ресурс] / Веб-сайт Київського медичного коледжу. - Режим доступу: http://www.kiev-medical.ru/ukr-method.htm. - дата доступу 26.02.2014.

16. Спірін О. М. Аналіз програмних платформ для створення інституційних репозитаріїв [Електронний ресурс] / Спірін О. М., Олексюк О. Р. // Інформаційні технології і засоби навчання. -

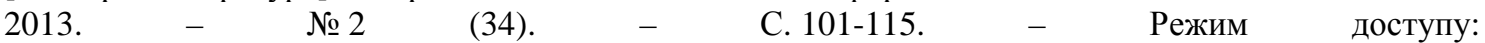
http://journal.iitta.gov.ua/index.php/itlt/article/view/821.

17. Спірін О. М. Концептуальні засади побудови мережі електронних бібліотек Національної академії педагогічних наук України [Електронний ресурс] / О. М. Спірін, С. М. Іванова, О. В. Новицький // Інформаційні технології і засоби навчання. - 2012. - № 5(32). - Режим доступу : http://journal.iitta.gov.ua/index.php/itlt/article/view/743/547.

18. Сучасні технології навчання [Електронний ресурс] / Веб-сайт Буковинського медичного університету режим доступу: http://www.bsmu.edu.ua/uk/edu/208-odern_technologies_-of_teaching. дата доступу 27.02.2014.

19. Яцишин А. В. Місце і роль мережі електронних бібліотек установ НАПН України в науковоосвітньому просторі [Електронний ресурс] / А. В. Яцишин // Інформаційні технології і засоби $\begin{array}{lllllll}\text { навчання. } & - & 2013 . & - & № 1 & \text { (33). }\end{array}$ http://journal.iitta.gov.ua/index.php/itlt/article/view/791.

Матеріал надійшов до редакиії 18.05.2015 p.

\title{
АКТУАЛЬНОСТЬ СОЗДАНИЯ ЭЛЕКТРОННОЙ БИБЛИОТЕКИ ВЫСШЕГО МЕДИЦИНСКОГО УЧЕБНОГО ЗАВЕДЕНИЯ УКРАИНЫ
}

\author{
Журавская Екатерина Александровна \\ аспирант \\ Институт информационных технологий и средств обучения НАПН Украины, г. Киев, Украина \\ Katerinazh@gmail.com
}

\begin{abstract}
Аннотация: Статья посвящена анализу наличия доступа к методической документации вуза на сайтах высших медицинских учебных заведений Украины. Проанализированы инструменты, которые обеспечивают этот процесс. Особое внимание уделено использованию электронных библиотек в медицинских вузах, рассмотрена проблема открытого доступа к методической информации. Освещены перспективы использования новейших информационных технологий в медицинской отрасли образования. Отмечается, что использование электронных библиотек позволит студентам медикам лучше овладевать знаниями и быть конкурентно способными специалистами, а учебное заведение повысит свой общественный рейтинг.
\end{abstract}

Ключевые слова: электронные библиотеки; веб сайт; медицинские учебные заведения; информационные технологии в образовании.

\section{ACTUALITY OF DIGITAL LIBRARIES CREATION IN THE HIGHER MEDICAL EDUCATIONAL INSTITUTIONS OF UKRAINE}

\author{
Kateryna O. Zhuravska \\ post-graduate student \\ Institute of Information Technologies and Learning Tools of NAES of Ukraine, Kyiv, Ukraine \\ Katerinazh@gmail.com
}


Abstract: This article deals with an access to methodical materials from the sites of higher medical educational establishments of Ukraine. The tools that provide the process are analyzed. Particular attention is paid to the use of digital libraries in medical universities, the problem of open access to methodological information is considered. The prospects of the use of the latest information technologies in the medical education industry are highlighted. It is noted, that the use of digital libraries will allow medical students to acquire better knowledge and to be competitive specialists, as well as higher establishments will improve their rating.

Keywords: digital libraries; Website; medical educational institutions; information technologies in education.

\section{REFERENCES (TRANSLATED AND TRANSLITERATED)}

1. Ambrushkevych J. G. Modern Information Technology in educational space of medical high school: Problems and Prospects / J.G. Ambrushkevych // Using informational and educational technology and learning electronic funds in universities: scientific materials of medical conference / Responsible editor V. A. Snezhytskyy. - Grodno: HrHMU, 2011. - P. 6-8 (in Russian).

2. Website of Vinnitsa Medical University. Pirogov [online] - Available from: http://www.vnmu.edu.ua/. Access date 27/02/2014 (in Ukrainian).

3. Website of Bukovina Medical University [online] - Available from: http: // http://www.bsmu.edu.ua/access date 12/04/2014 (in Ukrainian).

4. Website of Ternopil State Medical University. I. J. Gorbachevskogo [online]. - Available from: http://www.tdmu.edu.te.ua/ - access date 03/13/2014 (in Ukrainian).

5. Web site of Odessa Medical University [online]. - Available from: http: // www. odmu.edu.ua/ - access date 13/03/2014 (in Ukrainian).

6. Guschina L .N. Informational and educational high society technologies in schools / L. N. Guschina / Using informational and educational technology and learning electronical funds in vuze: scientific materials of medical conference / Responsible editor V. A. Snezhytskyy. - Grodno: HrHMU, 2011. - P. 40-43 (in Ukrainian).

7. Hrebenyk S. Analysis of the current state of medical education in colleges UK / S. Hrebeniuk / International cooperation of education in terms of globalization: materials of the second medical conference. - Simferopol: DYAYP, 2013. S.114-116 (in Russian).

8. Electronic library information systems research and educational institutions: monograph / [Spirin O. M., Ivanova S., Nowicki O.]; by science. ed. prof. V. U. Bykov, A. Spirina. - K .: educational thought, 2012. - 176 p. (in Ukrainian).

9. Using modern Internet technologies in educational process in the Department of Surgery GENERAL / Harelyk P. V. Marmysh G. G., Dubrovschyk O. I., Mohylevets E. V. / Using educational technology and learning electronical funds in vuze: scientific materials of the medical conference / Responsible editor V. A. Snezhytskyy. - Grodno: HrHMU, 2011. - P. 31-33 (in Ukrainian).

10. Features of teaching Oncology and Using telecommunications systems / A.V. Loaf, Uhlyanytsa K. N., Divinity G. G. et al. / Using educational technology and learning electronical funds in universities: scientific materials medical conference / Responsible editor V. A. Snezhytskyy. - Grodno: HrHMU, 2011. - P. 68-69 (in Ukrainian).

11. Transformation of Learning in knowledge, teaching methods [online] / Website of the Kiev Medical College. - Available from: http://www.kiev-medical.ru/ukr-method.htm. - Access date 26/02/2014 (in Russian).

12. Modern technology education [online] / Website of Bukovina Medical University. - Available from: http://www.bsmu.edu.ua/uk/edu/208-odern_technologies_-of_teaching. - Access date 27/02/2014 (in Ukrainian).

13. Oleksyuk O. R. Analysis of Electronic Resources in research work for future teachers Informatics [online] / O. R. Oleksyuk // Scientific notes. Series: problems of physical-mathematical methods and technological education. - №5. - 2014. - P. 43-48. (in Ukrainian).

14. Law of Ukraine on Libraries and Librarianship [online]. - Available from: http: //library.kr.ua/zakbibsprv.html. - Access date 04/26/2014 (in Russian).

15. The transformation of education in knowledge, teaching methods [online] / Website of the Kiev Medical College. - Available from: http://www.kiev-medical.ru/ukr-method.htm. - Date of access 26/02/2014 (in Ukrainian).

16. Spirin O. M. Analysis of software platforms for creating institutional repositories [online] / O. M. Spirin, O. R. Oleksyuk // Information technologies and means of teaching. - 2013. - № 2 (34). - P. 101-115. Available from: http://journal.iitta.gov.ua/index.php/itlt/article/view/821 (in Ukrainian).

17. Spirin O. M. Conceptual bases of network of electronic libraries of the National Academy of Pedagogical Sciences of Ukraine [online] / O. M. Spirin, S. M. Ivanova, O. V. Novitsky // Information technologies 
and means of teaching. - 2012. - № 5 (32). - Available from: http://journal.iitta.gov.ua/index.php/itlt/article/view/743/547 (in Ukrainian).

18. Modern technology education [online] / Website Bukovina Medical University. - Available from: http://www.bsmu.edu.ua/uk/edu/208-odern_technologies_-of_teaching. - Date of access 27/02/2014 (in Ukrainian).

19. Yatsyshyn A.V. Place and role of the network of electronic libraries of institutions NAPS of Ukraine in the scientific and educational space [online] / A.V. Yatsyshyn // Information technologies and means of teaching. - 2013. - №1 (33). - Available from: http://journal.iitta.gov.ua/index.php/itlt/article/view/791 (in Ukrainian). 